\title{
Wear of Engine Oils Using Gaseous Fuels
}

Vladimír Hönig, Matyáš Orsák

Faculty of Agrobiology, Food and Natural Resources, Department of Chemistry, Czech University of Life Sciences Prague, Kamýcká 129, 165 21, Prague 6 - Suchdol, Czech Republic, E-mail: honig@af.czu.cz, orsak@af.czu.cz

The article defines the specifications of engine oils used alternative fuels. Used particle analysis of exploited oils gives the results of the wear mode, which indicates the ratio of large and small wear particles contained in exploited oil. Another very important result is defined as the level of wear, which indicates the amount of wear particles contained in exploited oil. For the level of wear Thin Layer Chromatography was used. It was possible in practical terms to apply discriminant analysis based on the results of these tribodiagnostic methods. Nomogram the wear receives practical information of current oil and engine wear. On oil life and operational reliability of gas engines affected by the choice of oil, according to the specifications. Another parameter is the mode of operation of the engine and preventive maintenance. The results of the oil wear were significantly different and depended just on the current state of the engine. For engines in perfect condition low values of wear were measured, for engines in poor condition critical wear was detected.

Keywords: Pherrography, Engine Oil, Wear Particles, Nomogram the Wear, Discriminant Analysis

\section{References}

[1] ŠTĚRBA, P., KDYŽICKÝ, O. (2002) Jak na LPG. 1. vydání. pp. 10 - 78, Computer Press, Praha. Czech Republic.

[2] KAMEŠ, J. (2004). Alternativní pohony automobilů, 1. vydání. pp. 100 - 150. BEN, Praha. Czech Republic.

[3] HÖNIG, V., HROMÁDKO, J. (2014). Possibilities of using vegetable oil to power diesel engines as well as their impact on engine oil, Agronomy Research Vol. 12, No. 8, pp. 323 - 332. Estonian Agricultural University. Estonia.

[4] VESELÁ, K.., PEXA, M., MǍ̌íK, J. (2014). The effect of biofuels on the quality and purity of engine oil. Agronomy Research, Vol. 12, No. 2, pp. 425 - 430, Estonian Agricultural University. Estonia.

[5] ALEŠ, Z., PEXA, M., PAVLŮ, J. (2012). Tribotechnical diagnostics of agricultural machines, Engineering for Rural Development conference Jelgava, 24.-25.05.2012, [online]. [cit.2014-05.01] Available at www: http://www. http://tf.llu.lv.

[6] CELEBRANT, F., ZIEGLER, J., MARASOVÁ, D. (1996). Technická diagnostika a spolehlivost I. Tribodiagnostika. 1. vydání. pp. 110 - 138. VŠB-TU, Ostrava. Czech Republic.

[7] HÖNIG, V. (2015) Morphological Classification of Nonferrous Wear Particles in Engine Oil Using Pherrographical Method. Manufacturing Technology, Vol. 15, No. 4, pp. 530 - 534, J. E. Purkyne University in Ústí nad Labem nad Labem. Czech Republic.

[8] HÖNIG, V., MIHOLOVÁ, D., ORSÁK, M. (2014). Measurement of Wear Metals in Engine Oils by Atomic Absorption Spektrometry Method. Manufacturing Technology, Vol. 14, No. 3, PP. 317 - 322, J. E. Purkyne University in Ústí nad Labem nad Labem. Czech Republic.

[9] HÖNIG, V., SMRČKA, L., HORNÍČKOVÁ, Š. (2014). Application of discriminant analysis in monitoring the wear particles in the engine oil. Manufacturing Technology, Vol. 14, No. 3, pp. 322 - 326, J. E. Purkyne University in Ústí nad Labem nad Labem. Czech Republic.

[10] MIHALČOVÁ, J., HEKMAT, H. (2008).Tribotechnická diagnostika v prevádzke použitých olejov I. metódy hodnotenia častíc opotrebovania v olejoch, Chemické listy Vol. 102, pp. 358 - 362. Czech Society of Chemical Engineering, Prague, Czech Republic.

[11] Ministry of Defence CZ. (2007). Instruction for Tribodiagnostics of Engines, Gear and Hydraulic Systems, No. 79: 27/2007:3042, Logistics Division. Prague, Czech Republic.

[12] PEXA, M., ALEŠ, Z., PAVLU゚, J., ČEDÍK, J. (2015). Analysis of Wear Particles Morphology of Machine Parts Based on Aluminium. Manufacturing Technology, Vol. 15, No. 4, pp. 664 - 670, J. E. Purkyne University in Ústí nad Labem nad Labem. Czech Republic. 